\title{
An Exploratory Study Of The Variation In Unemployment Length Of Graduates Of Different Degree Programs
}

\author{
Steven Henry Dunga, North-West University, South Africa
}

\begin{abstract}
The drive to reduce poverty and unemployment in most developing or newly industrialized countries has many forms, the most common avenue, however, is the provision of education and a resultant expectation of employment. South Africa has in the past decade struggled with the issue of unemployment. Even in the face of very high graduate rates compared to other countries in the region, there is still high unemployment. The most common in South Africa is frictional as opposed to structural. An obvious expectation is that once people have attended tertiary education, getting a job should be easier than those without any education. However, there seems to be a mismatch between the skills required in the workplace and the skills the graduates looking for jobs have. Using data from graduates of one of the big universities in South Africa, the study investigated on the time, graduates take to get a job focusing on graduates from different degree programs. The results show that graduates eventually get employed but differences exist in the waiting period. The results show that of the six degree programs namely Bachelor of Commerce in Economics, BCom Human Resources, Bachelor of Arts Psychology, Bachelor of Education (BEd), Bachelor of Science and Bachelor of Arts in Law, the law degree graduates have the longest waiting period and the BEd has the shortest waiting period before getting employed. The study, however, showed that all the graduates in the sample were employed. The results also indicated that $58 \%$ of the graduates in the sample were not employed in the field they studied in. The study therefore recommended that to deal with unemployment in general, people should be afforded the opportunity to study for a degree, and that although low paying, BEd provides higher prospects of employment than most other degrees.
\end{abstract}

Keywords: Unemployment; South Africa; College Graduates; Education; Degree Programs

\section{INTRODUCTION}

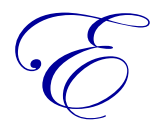

mployment through education and training remains one of the ways that guarantee getting out of poverty. The numbers of people graduating from higher education institutions have increased in a geometric rate in the $21^{\text {st }}$ century. On the flip side, the number of poor people in the world still stands at alarming levels. The Global monitoring report of (2014) indicate that 1/7 of the world population still lives below the poverty line of $\$ 1.25$ a day. Quoting the vice president and chief economist of the World Bank group, Kaushik Basu, the reports indicates that poverty is still high. That means approximately 1 billion people still live in extreme poverty. The two pronged solution of measuring success of economic development suggested by the World Bank Group (WBG) basically points at ending extreme poverty by reducing the number of people living below the $\$ 1.25$ a day to $3 \%$ and sharing prosperity which is essentially dealing with inequality. The World has the most billionaires now than at any point in time, and yet the number of poor people increased by more than 100 million in the last decade (Stark 2009). The oldest way of social mobility that has proven to be workable and sustainable has been to educate the poor so that they can live an independent life and fend for themselves as opposed to social security. Over the years, education has proven to be the most powerful tool in helping people to achieve upward social-economic mobility. The fact that highly educated graduates are now struggling to find jobs in most developing countries and hence alleviate themselves and their families from poverty becomes an area of concern (Mwesigwa 2014; Sharma 2014) There have been studies and reports that argue that graduate unemployment is just frictional as opposed to structural, and that all graduates end up getting a job all that matters is how long they wait (CDE 2013).

The unemployment rate in South Africa stands at $24.9 \%$ and of this very few are graduates. The graduate 
unemployment rate according to CDE (2013) was at 5\% and this was basically on account of graduates who are out of university and still looking for employment or people in between jobs. There are also other dimensions to the graduate unemployment rate that are consistent with the changes in the demographics of the people that have been graduating in the past 20 years. The report by the CDE point to the fact that more black students are now graduating from tertiary education making the graduate unemployment of blacks to be slightly higher than that of white people. The main objective of the study therefore is to explore the nature of graduate unemployment in South Africa by looking at the length it takes a graduate to secure a job. The hypothesis in this paper is that graduate unemployment in South Africa is frictional and hence the study considers how long graduates from different degree programs wait before they get their first job. The study also attempts to find out if there is structural unemployment disguised in people taking jobs below their qualification and outside the field of their specialization.

\section{LITERATURE REVIEW ON UNEMPLOYMENT AND YOUTH UNEMPLOYMENT IN SOUTH AFRICA}

Unemployment is a situation where a person in the working age category, who is actively seeking employment, is unable to find work or employment to earn them an income for a sustained period. Employment in a capitalist society is a way through which those that do not own factors of production can earn a living by selling their labour. The failure to obtain employment that earns wages or salaries paid in money is therefore what constitutes unemployment (Forstater 2002), This situation has dire consequences on the jobless themselves and is also associated with huge social and economic costs for society as a whole as this may be one of the main causes of poverty.

There are different types of unemployment. The three main types of unemployment are frictional, structural and cyclical. Other measures also include seasonal which occurs only during certain seasons and is common in the agricultural sector. In developing countries employment figures are inflated by including every little piece work that one does, in Malawi employment includes self-employment and subsistence farming in agriculture. These are misleading definitions, although they have been accepted by the ILO. Employment in its ordinary sense is supposed to be a way out of poverty and if the definitions are taken without careful consideration, policy directions that are supposed to assist in dealing with poverty cannot be enacted (Dunga 2014)

Unemployment continues to be a problem globally especially post 2008 financial crisis. The World Employment Social Outlook (2015) predicts that unemployment will continue to rise in the next 5 years. They pointed out that "over 201 million people were unemployed in 2014 around the world, over 31 million more than before the start of the global crisis. And, global unemployment is expected to increase by 3 million in 2015 and by a further 8 million in the following four years" (ILO 2015). Youth unemployment is, however, becoming more serious as the global figures continue to increase. The United Nations, World Youth Report reported that 75.8 million young people were unemployed in 2009 (ManpowerGroup 2012). In the Brenthurst Foundation report (2011). Oppenheimer and Spencer argue that South Africa has failed to increase formal sector employment largely because of labour laws that have made employment less attractive for employers due to higher wages and companies have resolved to capitalintensive ways of production (Oppenheimer \& Spicer 2011).

\subsection{Unemployment Trends in SA}

Unemployment seems to be a very perplexing state confronting South Africa. The country's past imbalances played and continued to play an important role in the country's development path as well as its unemployment problems. The official unemployment rate is approximately $26 \%$, and the expanded unemployment rate is estimated to be around $36 \%$ (STATSSA 2014). Even though a number of improvements including growth in employment have occurred in the country since the down of democracy in 1994, labour force growth has remained higher than the growth in jobs (Aurora \& Ricci 2005; Mahadea \& Simson 2010).

The economy's ability to absorb a large number of work seekers has been questionable, especially prior and post 1994. Between 1980 and 1994, the expanded unemployment rate increased enormously. By 1994, the unemployment rate had increased by $28 \%$. A similar trend is also observed in the official unemployment rate that also increased considerably since 1980 to 1994 ; from $11 \%$ to around $27 \%$. Many factors including the political 
tensions that divided the economy and the increased number of qualified black people contributed to the observed trend of unemployment in South Africa between 1980 and 1993 (STATSSA 2014). Figure 1 shows the trends in the unemployment between 1980 and 1993. JCP (2008) contend that one of the causes of the observed change was a shift in the production sector from labour intensive industries to capital intensive production with an aim to lessen their heavy dependence on the unstable and unpredictable South African labour market. This shift contributed to the increase in the unemployment rates (JCP, 2008:4).

Figure 1. Unemployment rates in South Africa (1980-1994)

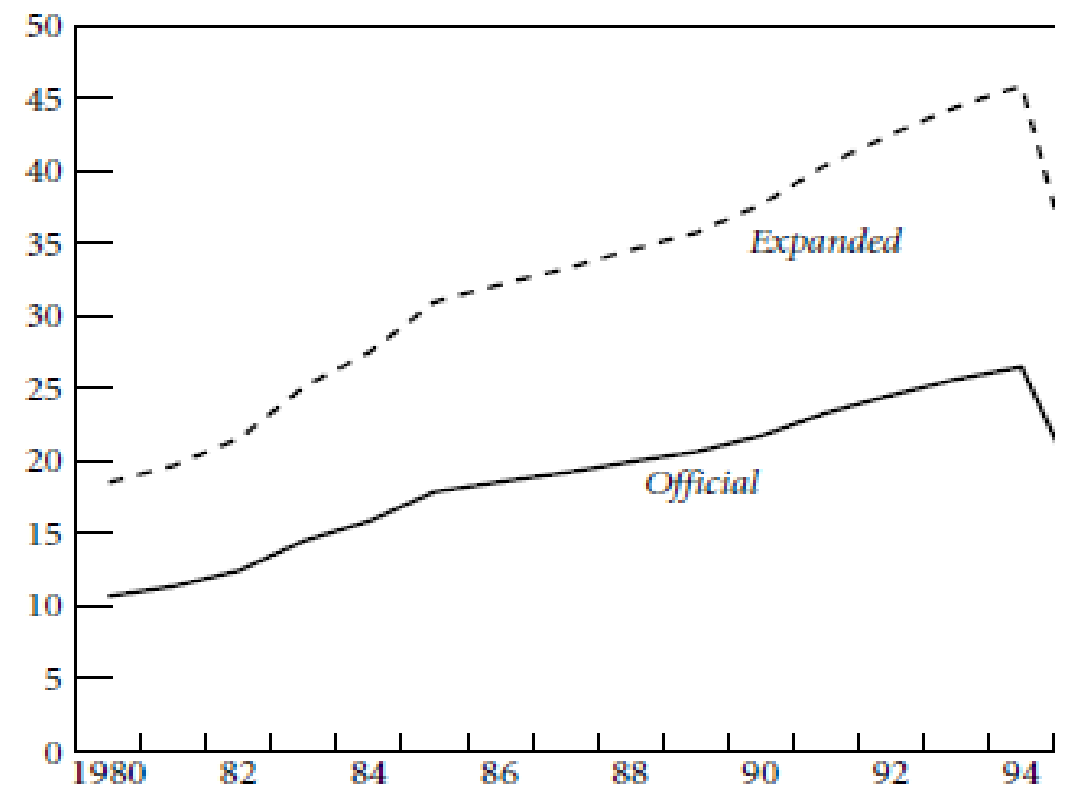

Source: Arora \& Ricci, 2006.

After 1994 as also shown by the trend in figure 1, unemployment started to decline. The change was mainly due to the policies implemented by the new democratic government which responded with many initiatives to address and speed up employment creation (Mahadea \& Simson 2010:391) Some of the policies introduced and implemented include the RDP, ASGISA, and GEAR among others. These policies played a significant role in containing the unemployment rate (Murwirapachena, 2010:25). The IDC (2014:21) reports that average annual employment growth increased from $0.5 \%$ over the period 1994 to 2000 to $1 \%$ during the years 2001 to 2007 (IDC 2014).

The beginning of the 2008 global recession had a severe impact on employment creation as more jobs were lost than created. According to Stats SA (2014), during 1994-2014, strict unemployment was $34.2 \%$ higher than employment growth. 
Table 1. Labour force in South Africa (1994-2014)

\begin{tabular}{|c|c|c|c|c|}
\hline & 1994 & 2014 & change & Change \% \\
\hline \multicolumn{5}{|l|}{ Strict } \\
\hline Employed (000) & 8896 & 15055 & 6159 & 69.2 \\
\hline Unemployed $(000)$ & 2489 & 5067 & 2578 & 103.4 \\
\hline Labour force $(000)$ & 11386 & 20122 & 8736 & 76.7 \\
\hline Unemployment rate & $22 \%$ & $25 \%$ & $+3.3 \%$ & - \\
\hline \multicolumn{5}{|l|}{ Expanded } \\
\hline Unemployed(000) & 4707 & 8157 & 3450 & 73.3 \\
\hline Labour force $(000)$ & 13603 & 23212 & 9609 & 70.6 \\
\hline Unemployment rate & $35 \%$ & $35 \%$ & unchanged & - \\
\hline
\end{tabular}

Source: Stats SA 2014

The expanded unemployment rate remained high in the last 20 years. Some of the reasons attributed to high numbers include labour markets instability and slow economic growth which made it difficult for the private sector and even the public sector to create new jobs (Leibbrandt et al. 2010:9) Between 1994 and 2012 the South African Economy managed to create 50,000 jobs annually (IDC 2014). And with the period of 1994 and 2013 the number of unemployed people rose to 4.8 million from 2.4 million (Stats SA 2012:91).

\subsection{Graduate Unemployment in SA}

Graduates are people with a higher education qualification. Studies indicate that graduate unemployment in South Africa is more prevalent amongst younger graduates than their older counterparts (CDE, 2013:13; National Treasury, 2011). The country has witnessed a surge in the number of graduates in the last two decades. The higher graduate unemployment is a result of increased access to higher education institutions for black people who were not initially. Moleke (2009:1) reveals that it remains a challenge for many of these graduates to find employment. There is also evidence that suggest that long periods of unemployment exist but these graduates eventually ends up getting a job (Stats SA, 2014; Kingdon \& Knight, 2006:295; Pauw et al., 2006).

It is argued that the level of unemployment among graduates is due to a serious oversupply of irrelevant skills as compared to the skills required by firms and the economy (Moleke, 2009; Nel \& Neale-Shutte, 2013). Many graduates lack the right education and skills, and even if they do get jobs, a lot of them remain underemployed (Shierholz et al., 2014:4). It remains to be proved as far as the mismatch is concerned. Some firms argue that it is difficult to find candidates with the right skills for vacant positions in their firms (Diamond, 2012; AEO, 2012; Career Builder, 2014).

Other studies have argued that graduates are not prepared for the world of work despite having tertiary qualifications (Acquah, 2009:28). The Economist (2012) reported that in South Africa about 600000 university graduates were unemployed while the private sector was struggling to fill an estimated 800000 vacancies (The Economist, 2012:5).

\subsection{Degree Choice and Job Prospects}

In looking at the level of unemployment, different aspects are considered to be determining the extent of the probability of getting a job or not getting a job. One important aspect especially when considering graduate unemployment is the degree one holds. Most countries have in recent year bemoaned the decline in numbers of qualified scientists. Basically, students have traditionally preferred business-oriented courses that are considered manageable and pays well in the job market.

\section{METHODOLOGY}

A random sample of 60 graduates from a South African University was collected in September 2014 in the preliminary stage of this study. The sample was spread to include graduates from the faculties at the campus and also to include all undergraduate degree programs on offer. The respondents that were involved in the survey were asked to indicate in months how long they were unemployed after they graduated from university. They were also asked to indicate the degree. 


\section{RESULTS AND DISCUSSION}

The results reported here are based on the preliminary sample of 60 graduates from a university in South Africa. A bigger sample is currently under the process of filling in the questionnaires that are distributed via email to the identified former students of the university. The data so collected will be used to conducted a deeper analysis of the idiosyncrasies of the graduates that get jobs easy and faster in comparison to those that struggle to get employment.

\subsection{Descriptive Statistics}

The preliminary sample comprises of 60 graduates and the gender distribution in the sample is as presented in Table 2. Out of the 60 graduates, $63.3 \%$ were females and 36.7 were males. This is not a diversion from the picture on the ground as the Centre for Higher Education (CHE) also pointed out in their 2008 report that there are more women in higher education compared to men (CHE 2010:4).

Table 2. Gender distribution of the sample

\begin{tabular}{l|c|c|c}
\hline \multicolumn{1}{c|}{ Gender } & Frequency & Percent (\%) & Cumulative percent (\%) \\
\hline Female & 38 & $63.3 \%$ & $63 \%$ \\
\hline Male & 22 & $36.7 \%$ & $100 \%$ \\
\hline Total & 60 & $100 \%$ & \\
\hline Source: Survey Data (2014) & &
\end{tabular}

The most important aspect of the study was to find out the time it takes a graduate to get employed and how it varies for graduates with different degree specialisations. Table 3 presents the descriptive statistics for the unemployment length for the sample. On average graduates wait at least three months, since the mean is 2.97 . The minimum waiting period recorded in the survey was one month and the maximum waiting period was six months. This agrees then with the study by CDE (2013) which contended that the graduate unemployment level is basically frictional unemployment emanating from graduates that have just finished school and are looking for employment that they eventually get.

Table 3. Descriptive statistics of Unemployment length

\begin{tabular}{l|c|c|c|c|c}
\hline & N & Minimum & Maximum & Mean & $\begin{array}{c}\text { Std. } \\
\text { Deviation }\end{array}$ \\
\hline Unemployment length in months & 60 & 1 & 6 & 2.97 & 1.931 \\
\hline
\end{tabular}

The results in Table three may however indicate underemployment if the people are not employed in jobs that utilise their full potential. The study, however, asked the respondents as to whether they are in a job of their field of study. Figure 2 presents a pie chart of the responses as to whether the job the respondents indicated to have was in the field of which they have a degree in. $58 \%$ of the respondents in the sample indicated that they were employed in a job that was not in the field of their specialisation. This then complicates the conclusion that graduate unemployment is frictional. The fact that, graduates are employed in fields they did not specialise in may indicate a number of issues. First it may indicate that graduates opt to get a lower paying and less than their qualification level job due to the absence of the necessary jobs, which may be an issue over supply of graduates hence jobs demanding employees with higher qualification for jobs that do not need any special skills. 
Figure 2. Job and Field of Study

\section{The job is in the field of study}

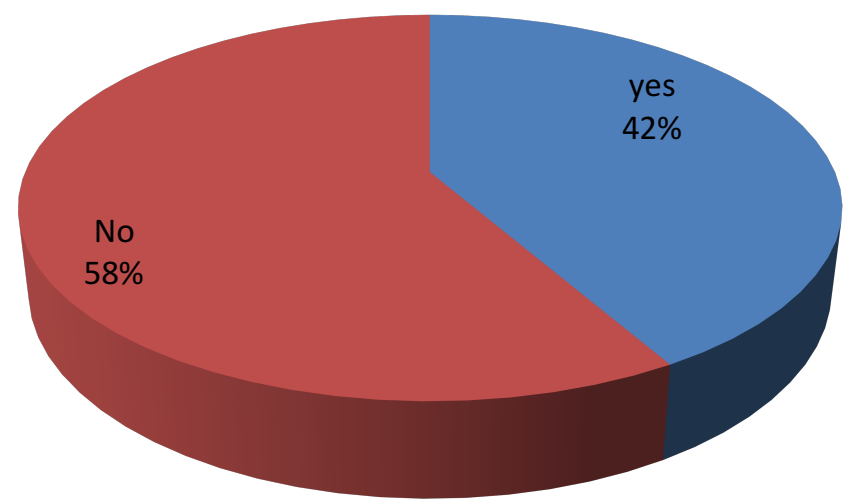

Source: Survey data

It may also indicate a structural unemployment problem. There may be a skills mismatch in the economy where people are trained in skills of qualifications that are not relevant to the available jobs in the economy. In which case, it would be necessary then to check as to what kind of qualifications the graduates are obtaining and what the need on the job market is. Table 4 present frequencies of the degree specialisation of the sample of graduates that were involved in the study.

Table 4. Degree Specialisation

\begin{tabular}{l|c|c|c|c}
\hline & Frequency & Percent (\%) & Valid Percent (\%) & Cumulative Percent (\%) \\
\hline BCom Economics & 12 & $20.0 \%$ & $20.0 \%$ & $20.0 \%$ \\
\hline BCom Human Resources & 9 & $15.0 \%$ & $15.0 \%$ & $35.0 \%$ \\
\hline BSc & 6 & $10.0 \%$ & $10.0 \%$ & $45.0 \%$ \\
\hline BA Psychology & 7 & $11.7 \%$ & $11.7 \%$ & $56.7 \%$ \\
\hline B Ed & 16 & $26.7 \%$ & $26.7 \%$ & $83.3 \%$ \\
\hline BA Law & 10 & $16.7 \%$ & $16.7 \%$ & $100.0 \%$ \\
\hline Total & 60 & $100 \%$ & $100 \%$ & \\
\hline
\end{tabular}

Source: Survey data

Table 4 shows that there is a wide range of degrees that students graduated with, Table 5 is a cross tabulation between the degree type and whether the graduate is in the field of their specialisation. Of those with BCom Economics, $58.3 \%$ were not employed in a job of that field while a lesser percentage was the case for those with BCom Human resources. 
Table 5. Specialisation and job type

What is the specialisation of your degree * The job is in the field of study Cross-tabulation

\begin{tabular}{|c|c|c|c|c|c|}
\hline & & & \multicolumn{2}{|c|}{ The job is in the field of study } & \multirow{2}{*}{ Total } \\
\hline & & & yes & no & \\
\hline \multirow{12}{*}{$\begin{array}{l}\text { What is the } \\
\text { specialisation of your } \\
\text { degree }\end{array}$} & \multirow{2}{*}{ BCom Economics } & Count & 5 & 7 & 12 \\
\hline & & $\%$ within field & $41.7 \%$ & $58.3 \%$ & $100.0 \%$ \\
\hline & \multirow{2}{*}{$\begin{array}{l}\text { BCom Human } \\
\text { Resources }\end{array}$} & Count & 6 & 3 & 9 \\
\hline & & $\%$ within field & $66.7 \%$ & $33.3 \%$ & $100.0 \%$ \\
\hline & \multirow{2}{*}{$\mathrm{BSc}$} & Count & 2 & 4 & 6 \\
\hline & & $\%$ within field & $33.3 \%$ & $66.7 \%$ & $100.0 \%$ \\
\hline & \multirow{2}{*}{ BA Psychology } & Count & 4 & 3 & 7 \\
\hline & & $\%$ within field & $57.1 \%$ & $42.9 \%$ & $100.0 \%$ \\
\hline & \multirow{2}{*}{ Bachelor of Education } & Count & 8 & 8 & 16 \\
\hline & & $\%$ within field & $50.0 \%$ & $50.0 \%$ & $100.0 \%$ \\
\hline & \multirow{2}{*}{ BA Law } & Count & 0 & 10 & 10 \\
\hline & & $\%$ within field & $0.0 \%$ & $100.0 \%$ & $100.0 \%$ \\
\hline \multirow{2}{*}{\multicolumn{2}{|c|}{ Total }} & Count & 25 & 35 & 60 \\
\hline & & $\%$ within field & $41.7 \%$ & $58.3 \%$ & $100.0 \%$ \\
\hline
\end{tabular}

Source: Survey data

The results in the Table five indicate how different degree choice may affect the chance of one finding a job in the field of their specialisation or not.

\subsection{Model Specification}

To assess further as to which degree specialisation had the lowest number of waiting months, an OLS regression was used with length of an employment as the dependent variable, and degree choice as the independent variables. The degree choice being a categorical variable an ANCOVA regression was employed as follows:

$$
G U L=\emptyset_{0}+\emptyset_{i} D_{i}+\cdots \emptyset_{n} D_{n}+\varepsilon
$$

Where GUL is graduate unemployment length, measured in months, $\emptyset_{0}$ is constant term that will capture the average unemployment length of the reference degree category, in this case, BCom in Economics. $\emptyset_{i}$ is the coefficient term associated with $\boldsymbol{D}_{\boldsymbol{i}}$ which is a dummy variable for degree category i. Hence the model to be estimated is as follows:

$$
G U L=\emptyset_{0}+\emptyset_{1} D_{1}+\emptyset_{2} D_{2}+\emptyset_{3} D_{3}+\emptyset_{4} D_{4}+\emptyset_{5} D_{5}+\varepsilon
$$

Where the dummy variables are defined as follows; BCom Economics is the reference category, Bachelor of Commerce Human resources is $\mathrm{D}_{1}$, Bachelor of Science (BSC) is $\mathrm{D}_{2}$, Bachelor of Arts Psychology is $\mathrm{D}_{3}$, Bachelor of Education (BEd) is $\mathrm{D}_{4}$ and Bachelor of Law (BA Law) is $\mathrm{D}_{5}$.

\subsection{Results and Discussion of the OLS ANOVA Model}

The OLS model with the degree choice as dependent variables shows a high R-squared of $96 \%$ the model fitness test presented by the $\mathrm{F}$ test is also significant at $1 \%$ with a p-value of 0.000 . The regression results are presented in Table six. 
Table 6. Regression Results

\begin{tabular}{|c|c|c|c|c|c|c|}
\hline & \multirow{3}{*}{ Model } & \multicolumn{3}{|c|}{ Coefficients } & \multirow{3}{*}{$\mathbf{t}$} & \multirow{3}{*}{ Sig. } \\
\hline & & \multicolumn{2}{|c|}{$\begin{array}{c}\text { Unstandardized } \\
\text { Coefficients }\end{array}$} & \multirow{2}{*}{$\begin{array}{c}\begin{array}{c}\text { Standardized } \\
\text { Coefficients }\end{array} \\
\text { Beta }\end{array}$} & & \\
\hline & & B & Std. Error & & & \\
\hline \multirow{7}{*}{1} & (Constant) & 2.500 & .162 & & 15.418 & .000 \\
\hline & Bachelor of Human Resources & .611 & .248 & .114 & 2.467 & .017 \\
\hline & $\mathrm{BSC}$ & -1.167 & .281 & -.183 & -4.154 & .000 \\
\hline & BA Psychology & 3.071 & .267 & .515 & 11.498 & .000 \\
\hline & Bachelor of Education & -1.500 & .214 & -.346 & -6.993 & .000 \\
\hline & BA Law & 3.200 & .240 & .623 & 13.306 & .000 \\
\hline & (Constant) & 2.500 & .162 & & 15.418 & .000 \\
\hline
\end{tabular}

a. Dependent Variable: Unemployment length

The results indicate the average length of unemployment for each degree category. The constant represent the length for the base category which is BCom Economics. The results indicate that graduates with a BCom Economics wait 2.5 months before they get employed. Graduates with a Bachelors of Law are the once with the highest unemployed period of 5.7 months. The degree category that has the lowest unemployed period is those with a Bachelor of Education degree with an average unemployment length of 1 month. Those with a bachelor's of Science also have a shorter unemployment period of 1.33 Bachelor of Arts in Psychology has the second highest unemployment length of 5.57 months. These results indicate therefore that different degree choices have different potentials in affording the holders a chance of a job. This may point to the fact that certain sectors are saturated while other sectors still have vacancies and hence can help in deciding on which programs should produce more graduates. The fact that graduates with education degree do not wait long before getting a job point to an already known fact that demand for teachers is always high.

The results also agree with the results in Table five which indicated whether the graduates are employed in their field of study. Results of Table five indicated that all the graduates with a BA Law were employed in a job in a different career other than that which they studied for. It is also interesting to note that there are people with bachelor of education which indicated that they were employed outside their field of study. This may indicate that they have a job better than the teaching job, since the results indicate that there are enough teaching jobs.

\section{CONCLUSION}

The paper investigated on the nature of graduate unemployment in South Africa, with a premise that it is frictional. Using an Anova regression model, the results presented the average waiting period before one secures a job. The results show that graduates on average do not stay that long without a job. The average unemployment for the graduates in the sample was three months. However the study also found that the majority of the graduates in the sample up to $58 \%$ were not employed in the field of their specialisation, which then led to the question as to whether there are some structural problems in the economy as to have so many graduates doing jobs other than what they were trained for. It was also argued that it can be an indication of an over-supply of graduate. with the creating of the corresponding jobs by both the government and the private sector the waiting period can be reduced substantially. The study creates the need for further investigation into what are these jobs that are taking people with other specializations. It would have been good also to establish whether the job outside field of study were better or lower than what they would get if they were in their field of study.

The results of the study have shown that degree programs play a crucial role in employment chances. The Bachelor of education has the highest employment potential, and the bachelor of law has the lowest employment potential. From this study, it can be stated that graduate unemployment in South Africa may indeed be frictional as opposed to structural and that graduates may wait for varying length but they eventually get employed.

The recommendations from this study are that, there should be better ways of linking employers and job seekers. Thus there may be room for a creation of recruitment agencies that would have the list of all jobs available on the market where graduates can access and register themselves. This would help reduce the waiting period before one secures a job. Government should continue to motivate private companies to take fresh graduates for internship. 
Another clear issue coming out clear is that individuals deciding on a career path should know that good paying jobs, like law, may have a longer waiting period than those that pay relatively less like education.

\section{REFERENCES}

Acquah, A. 2009. Tertiary graduates: Earnings and employment prospects in the South African labour market. Southern African Review of Education, 15(2):27-44.

AEO, 2012. Promoting youth unemployment. http://www.africaneconomicoutlook.org/fileadmin/uploads/PAGES\%20Pocket\%20Edition\%20AEO2012-EN.pdf [Accessed Dec,15 2014].

Aurora, V. \& Ricci, L.., 2005. Unemployment and the labour market. In Post-Apartheid South Africa: the first ten years. Washington, DC.: IMF, pp. 23-47.

Career Builder. 2014. The shocking truth about the skills gap. http://www.careerbuildercommunications.com/pdf/skills-gap2014.pdf [Accessed Feb 25, 2015]

CDE, 2013. Graduate Unemployment In South Africa A much exaggerated problem, Johannesburg.

CHE, 2010. Higher Education in South Africa Data 2008 Who Participates in Higher Education ?, (February), pp.1-15.

Diamond, P. 2012. Cyclical unemployment, structural unemployment. 13th Jacques Polak Annual Research Conference, November 8-9, 2012. https://www.imf.org/external/np/res/seminars/2012/arc/pdf/PD2.pdf [Accessed Dec 15, 2014]

Dunga, S.H., 2014. The Channels Of Poverty Reduction In Malawi : A District Level Analysis By. North-Wlest University, Vaal Triangle Campus.

Forstater, M., 2002. Unemployment, Kansas City.

IDC, 2014. Economic Trends in the South African economy. Available at: http://www.idc.co.za/images/download-files/researchreports/Economic_Trends_Key_trends_in_SA_economy [Accessed January 10, 2015].

ILO, 2015. World Employment Social Outlook: Trends 2015, Geneva.

Kingdon, G. \& Knight, J. 2005. Unemployment in South Africa, 1995-2003: causes, problems and policies. http://www.csae.ox.ac.uk/conferences/2006-eoi-rpi/papers/csae/kingdon.pdf [Accessed Jan 22, 2015]

Leibbrandt, M. et al., 2010. Employment and inequality outcomes in South Africa. Available at: http://www.oecd.org/employment/emp/45282868.pdf [Accessed April 15, 2015].

Mahadea, D. \& Simson, R., 2010. . The challenge of "low employment growth" in South Africa: 1994 - 2008. SAJEMS, 13(4), pp.391-406.

ManpowerGroup, 2012. Youth Unemployment Challenge And Solutions,

Moleke, P. 2009. Chapter 6: The graduate labour market. Cape Town. HSRC Press.

Mwesigwa, A., 2014. Uganda's unemployed graduates held back by skills gap. The Guardian.

Nel, H. \& Neale-Shutte, M. 2013. Examining the evidence: graduate employability at NMMU. South African Journal of Higher Education, 27(2): 437-453.

Oppenheimer, J. \& Spicer, M., 2011. Addressing Africa's youth unemployment crisis: Creating Employment in Africa,

Pauw, K., Ooosthuizen, M. \& Van Der Westhuizen, C. 2006. Graduate unemployment in the face of skills shortage: a labour market paradox. Working Papers 06/114, University of Cape Town, Development Policy Research Unit.

Sharma, Y., 2014. What do you do with millions of extra graduates? BBC.

Shierholz, H., Davis, A. \& Kimball, W. 2014. The class of 2014: The weak economy is idling too many young graduates. EPI Briefing paper 377. Economic Policy Institute.

Stark, B.J., 2009. Theories of Poverty / The Poverty of Theory. Brigham Young Univereity Law Review, 381(425).

STATSSA, 2014. Natiional and provincial labour market: Youth,

Stryker, J.D., Cassim, F., Rajaratnam, B., Bhorat, H., Leibbrandt, M. \& Plunkett, D. 2001. Increasing demand for labour in South Africa. http://pdf.usaid.gov/pdf_docs/PNACM723.pdf [Accessed March 8, 2015]

The Economist. 2012. Education in South Africa is still dysfunctional. http://www.economist.com/node/21543214 [Accessed Dec 20, 2014] 


\section{NOTES}

